\title{
PENGGUNAAN VISUAL DAN CERITA DALAM PROMOSI SECARA ONLINE UNTUK MEMPERKENALKAN BATIK CIPRATAN SLB NEGERI SEMARANG JAWA TENGAH
}

\author{
Noeratri Andanwerti ${ }^{1}$, Siti Nurannisaa P.B. ${ }^{2}$, Niken Widi Astuti ${ }^{3}$ \\ ${ }^{1}$ Program Studi Desain Interior, Universitas Tarumanagara Jakarta \\ Email:noeratria@fsrd.untar.ac.id \\ ${ }^{2}$ Program Studi Desain Komunikasi Visual, Universitas Tarumanagara Jakarta \\ Email: sitip@fsrd.untar.ac.id \\ ${ }^{3}$ Program Studi Psikologi, Universitas Tarumanagara Jakarta \\ Email: nikenw@fpsi.untar.ac.id
}

\begin{abstract}
ABSTRAK
Dalam upaya mengenalkan suatu produk, dibutuhkan wawasan dan pengetahuan mengenai promosi. Konten visual dan cerita merupakan beberapa komponen yang perlu dimiliki dalam proses promosi. Media sosial saat ini telah mencakup semua saluran komunikasi dan alat media yang semakin sering digunakan untuk menghubungkan antar individu yang tersebar. Perkembangan media sosial ke dalam kehidupan sehari-hari telah mempengaruhi cara konsumen berinteraksi dan berperilaku di seluruh dunia. Media sosial bisa menjadi salah satu pilihan media dalam melakukan promosi. SLB Negeri Semarang adalah salah satu sekolah yang memiliki produk ungggulan yaitu Batik Cipratan. Batik tersebut telah dikenal masyarakat karena keunikan dalam teknik produksinya. Promosi produk Batik Cipratan saat ini masih menggunakan cara konvensional. Fakultas Seni Rupa dan Desain (FSRD) melalui tim pengabdian masyarakat mencoba memfasilitasi kebutuhan SLB Negeri Semarang untuk menciptakan perencanaan promosi menggunakan media sosial secara online. Kegiatan ini bertujuan untuk dapat mendukung proses pengenalan dan promosi produk Batik Cipratan. Kegiatan ini menggunakan metode belajar class room training yaitu memberikan pelatihan dalam ruang-ruang kelas sesuai dengan topik yang dibutuhkan. Pelatihan ini memberikan pengetahuan dan wawasan bagi SLB Negeri Semarang untuk dapat mengoptimalkan proses promosi yang telah dilakukan sebelumnya. Untuk kedepan diperlukan langkah pembentukan tim khusus dari pihak sekolah dalam melakukan promosi lebih lanjut. Hasil dari pelatihan ini, para guru diharapkan memiliki pemahaman mengenai pengelolaan media dalam menyusun perencanaan promosi yang akan dilakukan dengan elemen visual dan cerita yang dapat jadi kekuatan dalam mengenalkan produk.
\end{abstract}

Kata kunci: promosi, media, sosial, online, visual, cerita

\section{PENDAHULUAN}

Promosi dan pengenalan produk menjadi sebuah kebutuhan dalam menghadapi perubahan yang semakin cepat di berbagai bidang. Perubahan, menjadi kondisi yang perlu dihadapi dan diantisipasi pada zaman ini. Lembaga pendidikan yang dalam proses pembelajarannya menghasilkan produk menjadi salah satu bidang yang membutuhkan berbagai persiapan dalam menghadapi perubahan tersebut. Dalam upaya mengenalkan suatu produk tersebut, dibutuhkan peran serta berbagai keilmuan yang dapat saling membantu untuk memberikan pengetahuan dan wawasan terkait. Salah satu yang dapat dilakukan, khususnya bagi pendidikan tinggi adalah berpartisipasi dalam program pengabdian pada masyarakat.

Program Pengabdian Kepada Masyarakat merupakan bagian dari Tridharma Perguruan Tinggi yang ditujukan untuk semua lapisan masyarakat. Dalam hal ini, Universitas Tarumanagara (UNTAR) Jakarta memiliki berbagai bidang kepakaran, salah satunya adalah seni rupa dan desain yang dikelola oleh Fakultas Seni Rupa dan Desain (FSRD). Kegiatan ini dilakukan oleh dosen dan melibatkan mahasiswa. Pendidikan seni rupa dan desain diharapkan dapat 
memberikan kontribusi keilmuan untuk membangun lingkungan kreatif di sekolah-sekolah melalui berbagai program pelatihan. Program ini diharapkan dapat menjadi embrio dalam membangun pengetahuan dan wawasan mengenai promosi di sekolah-sekolah.

SLB Negeri Semarang adalah salah satu sekolah yang dikenal memiliki ciri khas dalam salah satu kegiatan ekstra-kurikuler kreatifnya yaitu pembuatan Batik Cipratan. Kegitan ekstrakurikuler ini dilakukan guna melatih siswa untuk mengembangkan potensi non akademik dan keterampilan khususnya dalam membatik. Kegiatan ekstra-kurikuler membatik di SLB Negeri Semarang dirintis oleh Bapak Drs. Ciptono sebagai kepala kekolah sejak tahun 2011. Batik Cipratan yang diproduksi siswa siswai SLB Negeri Semarang telah dikenal masyarakat karena keunikan dalam teknik produksinya.

Tujuan untuk kemandirian dan produktivitas siswa yang menjadi bekal dalam kehidupannya setelah selesai masa sekolah menjadi latar belakang dari dibuatnya aktivitas pembuatan Batik Cipratan ini. Keinginan dan semangat para siswa untuk dapat melanjutkan kehidupan dengan kekuatan sendiri menjadi kekuatan SLB Negeri Semarang untuk melaksanakan program ektrakurikuler ini. Para siswa ingin menunjukkan bahwa dengan keterbatasan, mereka mampu menghasilkan sesuatu yang bernilai ekonomi tinggi sehingga nanti bisa menopang kehidupannya. Hal ini ditunjukkan dengan penjualan Batik Cipratan yang cukup banyak. Para peminat batik ini membeli bukan karena faktor 'kasihan', namun memang karena kualitas dan kreativitas motif yang dihasilkan. Saat ini karya batik para siswa SLB Negeri Semarang semakin banyak diminati, tidak hanya masyarakat Jawa Tengah, bahkan wisatawan Brunei Darusalam dan Eropa. Ini menjadi salah satu bukti bahwa keberadaan karya Batik Cipratan dari siswa SLB Negeri Semarang memiliki kualitas dan daya saing cukup tinggi.

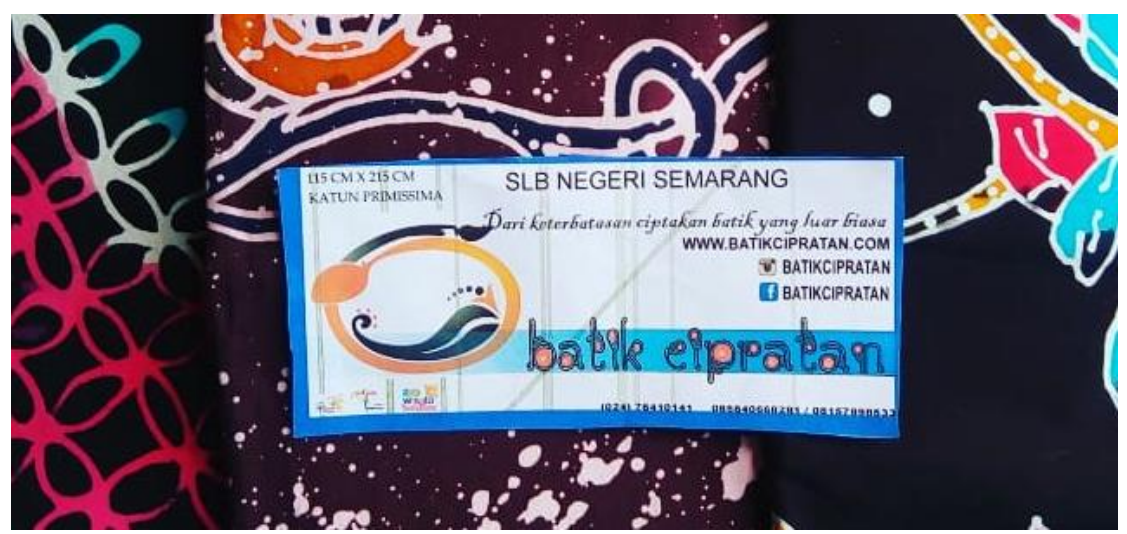

Gambar 1. Media promosi produk Batik Cipratan

Dalam proses penciptaaan karya Batik Cipratan ini salah satu tantangan yang dihadapi adalah melakukan pengembangan, khususnya pengenalan dan promosi lebih luas. Menurut Ibu Fanie Dipa Pawakaningsih, M. Pd. salah seorang guru SMALB Tuna Rungu, "Batik Cipratan SLB Negeri Semarang sudah banyak ditiru sekolah-sekolah lain, kami perlu pengembangan desain serta promosinya". Hal ini diperkuat oleh pernyataan Ibu Choirun Nisa, salah seorang guru keterampilan batik, yang menyatakan bahwa diperlukan pelatihan untuk guru dan siswa dalam pengembangan desain dan promosinya agar dapat lebih dikenal masyarakat. Pendekatan media promosi produk Batik Cipratan SLBN Semarang saat ini masih menggunakan cara konvensional, menggunakan semacam kertas label yang diselipkan dalam kemasan plastik pembungkus, yang berisi informasi tentang nama produk, ukuran, motto dan kontak seperti pada Gambar 1. 
Menurut Arif Rahman (2017) pembuatan media promosi yang sesuai dengan perkembangan masyarakat saat ini, salah satunya adalah melalui cerita. Produk harus memiliki cerita atau dibuat kisahnya seolah produk itu memiliki nilai historis. Bagi pengamat atau pembeli, kata-kata yang disusun mengisahkan sebuah produk tentang latar belakang, sejarah, proses pembuatan, material yang digunakan, siapa yang membuat, akan menambah daya tarik bagi produk tersebut dan menimbulkan apresiasi.

Jika saat ini konten cerita merupakan salah satu yang perlu dimiliki dalam proses promosi, maka media yang juga perlu dipilih dalam promosi adalah media yang saat ini banyak digunakan, yaitu sosial media. Media sosial saat ini telah mencakup semua saluran komunikasi dan alat media yang semakin sering digunakan untuk menghubungkan antar individu yang tersebar. Jaringan media sosial secara online mampu mempromosikan ide dan gagasan baru dengan lebih cepat (Ulanat \& Jacob, 2017) . Perkembangan media sosial ke dalam kehidupan sehari-hari telah mempengaruhi cara konsumen berinteraksi dan berperilaku di seluruh dunia. Dengan demikian media sosial bisa menjadi salah satu pilihan media dalam melakukan promosi.

Sedangkan untuk tujuan jangka panjang, promosi produk untuk meningkatkan pemasaran, menurut Wardhana (2015) strategi pemasaran digital berpengaruh terhadap keunggulan bersaing, secara berurutan mulai dari yang paling dominan yaitu: kemudahan pencarian produk, ketersediaan penawaran khusus, kemampuan mengidentifikasi dan menarik pelanggan baru ketersediaan informasi produk atau artikel-artikel yang mendukung dan memberikan panduan produk bagi konsumen, kemampuan menciptakan visibiltas dan kesadaran merek, kemampuan penguatan citra merek yang diterima oleh konsumen, ketersediaan tampilan testimonial, ketersediaan sajian informasi terbaru melalui sms-blog, ketersediaan bantuan pelayanan kepada konsumen, ketersediaan komunikasi online dengan pengusaha, ketersediaan dukungan opini online, ketersediaan gambar-gambar pendukung yang dibutuhkan seperti foto-foto atau ilustrasi produk, ketersediaan tampilan video yang mampu memvisualisasikan produk atau presentasipresentasi pendukung, ketersediaan alat transaksi dan variasi media pembayaran, ketersediaan lampiran dokumen dan ketersediaan catatan pengunjung.

Optimalisasi penggunaan media sosial dan website perlu dilakukan mengingat masih terdapat kekurangan pada website maupun media sosial yang digunakan UKM seperti kurang informatif, kurang interaktif dan kurang update.

Berdasarkan keadaan tersebut, maka Fakultas Seni Rupa dan Desain (FSRD) melalui tim pengabdian masyarakat mencoba memfasilitasi kebutuhan SLB Negeri Semarang melalui kegiatan untuk menciptakan perencanaan promosi dalam pembuatan Batik Cipratan. Kegiatan ini dilakukan dalam bentuk pelatihan "Pengembangan Desain Dan Promosi Batik Cipratan Sebagai Kegiatan Unggulan SLB Negeri Semarang Jawa Tengah". Pelatihan ini bertujuan untuk meningkatkan kreativitas siswa dan guru dalam pengembangan desain dan media promosi. Pelatihan ini diharapkan dapat membantu kegiatan ekstra kurikuler Batik Cipratan yang menjadi unggulan SLB Negeri Semarang. Pelatihan ini akan melibatkan guru dan siswa, diharapkan melalui kegiatan ini dapat pula mendukung proses pengenalan dan promosi produk. Penekanan pelatihan ini adalah pada pengembangan proses berpikir kreatif dalam melakukan eksplorasi gagasan pada pembuatan promosi Batik Cipratan. 


\section{METODE PELAKSANAAN PKM}

Dalam pelaksanaan program pelatihan ini, tahapan awal yang dilakukan terlebih dahulu adalah melakukan proses diskusi sebagai persiapan. Untuk medapatkan kelengkapan informasi tentang kebutuhan pelatihan, maka diskusi awal dilakukan dengan pihak sekolah (guru) dari SLB Negeri Semarang. Dalam diskusi tersebut ditemukan bahwa pihak sekolah memerlukan pengetahuan mengenai tahapan dalam melakukan promosi melalui berbagai media, khususnya penggunaan media sosial secara online.

Kegiatan pelatihan pengembangan media promosi ini akan menggunakan metode belajar Class room training yaitu memberikan pelatihan dalam ruang-ruang kelas sesuai dengan topik yang dibutuhkan oleh para peserta dengan cara pemberian materi melalui ceramah, kemudian dilanjutkan dengan praktika dengan mengajak para peserta melakukan proses diskusi dalam menggali cerita dan mengeksplorasi ide tersebut untuk digunakan sebagai konten dalam promosi dan menentukan perencanaan media yang akan digunakan menggunakan kertas kerja.

\section{HASIL DAN PEMBAHASAN}

Kegiatan awal yang dilakukan adalah dengan melakukan perancangan materi pelatihan yang akan digunakan. Pada sesi ini peserta yang diikutsertakan adalah khusus para guru. Diharapkan nantinya guru pendamping mata pelajaran membatik ini dapat mengembangkan perencanaan tahapan promosi. Materi disusun dengan kebutuhan promosi yang sebagian besar menggunakan media sosial secara online. Dalam melakukan promosi penjualan sebuah produk diperlukan beberapa komponen yaitu adanya logo, produk dan media promosi. Oleh karena itu pada tahapan ini dilakukan langkah sebagai berikut.

1. Identifikasi komponen penjualan produk yang telah dimiliki

2. Pengumpulan media promosi yang telah dilakukan sebelumnya oleh SLB Negeri Semarang

3. Proses analisis kebutuhan dan sasaran khalayak

4. Pembuatan perencanaan media

Berdasarkan hasil analisis SLB Negeri Semarang telah memiliki kelengkapan komponen penjualan dan beberapa media sosial yang dibutuhkan dalam proses promosi diantaranya yaitu : 1) situs atau website, 2) akun Facebook dan 3) akun Instagram. Gambar 2 menampilkan halaman media online tersebut.
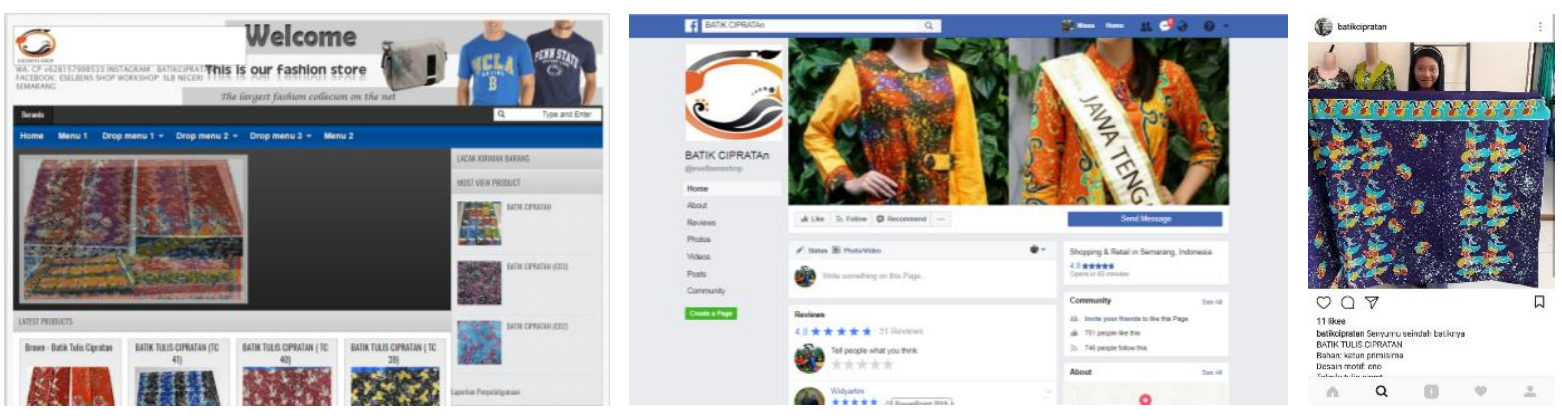

Gambar 2. Situs, akun facebook dan akun Instagram SLB Negeri Semarang (Sumber: Facebook.com \& Instagram.com

Ketiga media tersebut memiliki potensi untuk dikembangkan melalui pengembangan konten. Salah satu kekuatan dari SLB Negeri Semarang adalah memiliki cerita. Pada proses pembelajaran membatik yang dilakukan oleh sekolah ini banyak kejadian dan keadaan yang bisa 
digali lebih lanjut sebagai sebuah kekuatan cerita. Langkah selanjutnya adalah membuat rumusan alur pelatihan yaitu dengan materi mengenai pengenalan penggunaan media sosial dan cara menggali cerita dalam merumuskan konten.

\section{Penggunaan Media Sosial}

Berdasarkan hasil analisis, SLB Negeri Semarang membutuhkan pembuatan situs dan media sosial, karena sebelumnya telah ada. Hal yang dibutuhkan adalah bagaimana mengelola dan membuat perencanaan dalam menggunakan media tersebut. Penggunaan media cetak konvensional saat ini membutuhkan lebih banyak biaya, dengan tingkat sebaran yang tidak seluas media online. Berdasarkan data tersebut maka langkah yang bisa dilakukan dalam promosi Batik Cipratan dapat dilihat pada Gambar 3.

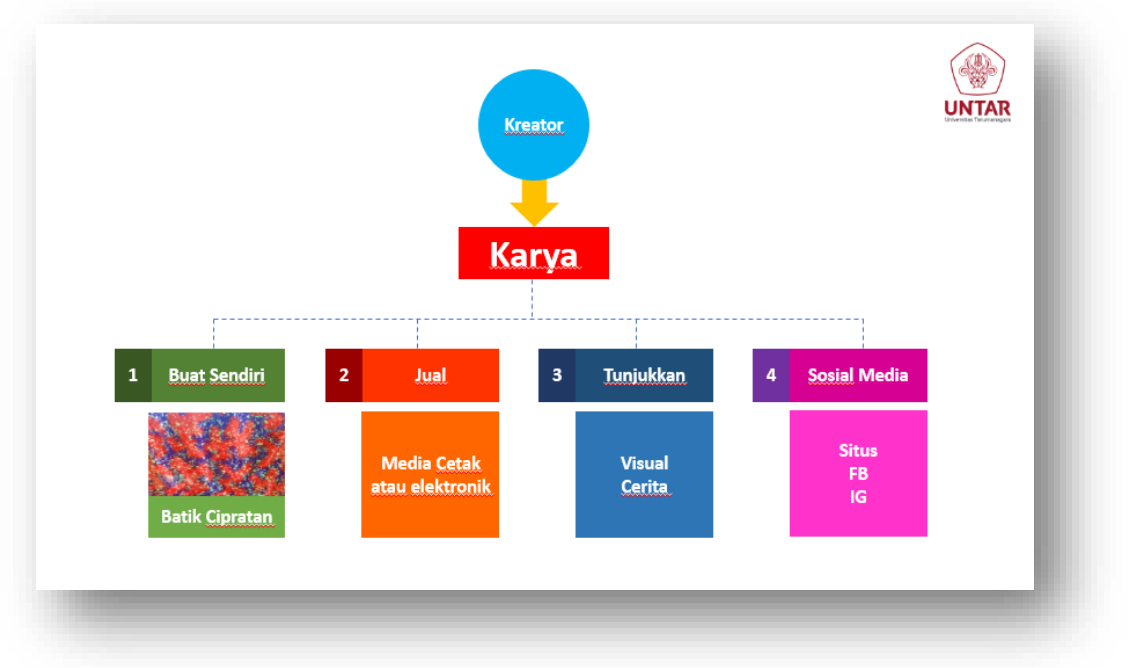

Gambar 3. Alur pembuatan promosi melalui media online

Pada materi pelatihan, peserta mendapat penjelasan mengenai setiap tahapan yang dilakukan dan langsung melakukan diskusi, merumuskan bagian mana saja yang sudah dimiliki dan perlu dikembangkan.

\section{Perancangan Visual}

Visual mengekspresikan ide dengan cara yang bisa diterima secara mudah. Visual menampilkan suatu objek atau kejadian atau keadaan pada suatu waktu tertentu yang dapat menggugah emosi. Karya Batik Cipratan yang memiliki karakteristik motifnya yang khas, jika divisualisasikan dengan cara dan Teknik yang tepat dapat menjadi kekuatan dalam visual saat promosi dilakukan. Visual menjadi salah satu kekuatan media sosial online yang mampu menarik peminat untuk melihatnya. Pada materi ini disampaikan beberapa hal dasar terkait cara dan teknik dalam menyusun tata letak visual, pemilihan jenis visual dan teks yang sesuai bagi konsumen.

\section{Menggali Konten Cerita}

Salah satu ciri khas Batik Cipratan adalah cara atau proses membatik yang dilakukan. Keterbatasan siswa dalam melakukan sebuah aktivitas denggan kompleksitas tinggi menginspirasi guru untuk dapat melakukan pembuatan motif dengan cara sederhana. Setelah dilakukan berbagai proses percobaan, maka metode membatik yang paling disenangi oleh siswa adalah dengan menciprat warna menggunakan sendok. Seiring dengan perjalanannya, maka 
proses ini justru menjadi ciri khas dalam motif yang dihasilkan. Maka disebut dengan Batik Cipratan.

Tidak hanya proses awal mulanya saja, namun ternyata dalam proses pengerjaan batiknya terdapat berbagai cerita yang bisa digali untuk menjadi konten dalam pembuatan promosi. Saat ini cerita adalah nilai yang paling mahal dari sebuah barang. Manusia senang berbagi cerita. Cerita sederhana dan mudah dipahami. "Beri cerita pada semua karya yang kita ciptakan. Semakin baik cerita semakin dikenal karya kita dibenak konsumen". Untuk membantu para guru, maka dibuatkan buku kerja untuk memudahkan dalam melakukan perencanaan promosi. Pada Gambar 4 merupakan isi dari lembar kerja perencanaan dan Gambar 5 menampilkan keseluruhan buku kerja yang berisi lembar kerja, alat tulis spidol, cap dan tempat perlengkapan.

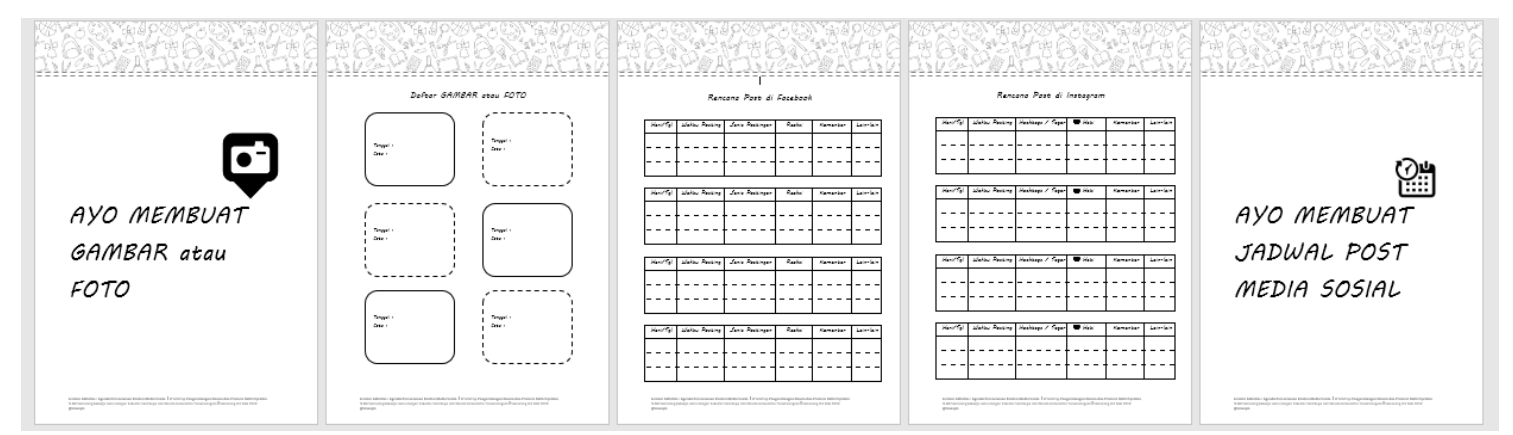

Gambar 4. Lembar kerja perencanaan promosi

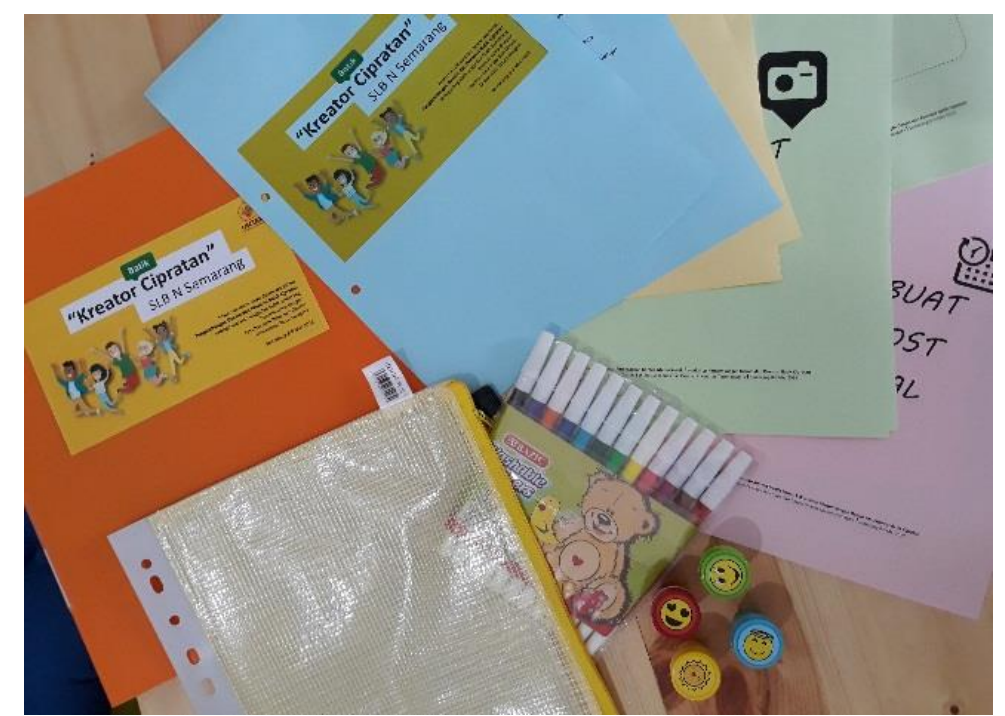

Gambar 5. Buku kerja perencanaan promosi

Pelaksanaan Pelatihan

Pada sesi pelatihan ini para guru mengungkapkan bahwa banyak sekali cerita yang dapat disajikan. Para guru mencoba mengekplorasi berbagai sisi cerita yang dapat digunakan sebagai konten cerita. Gambar 6, menunjukkan saat suasana pelatihan. 

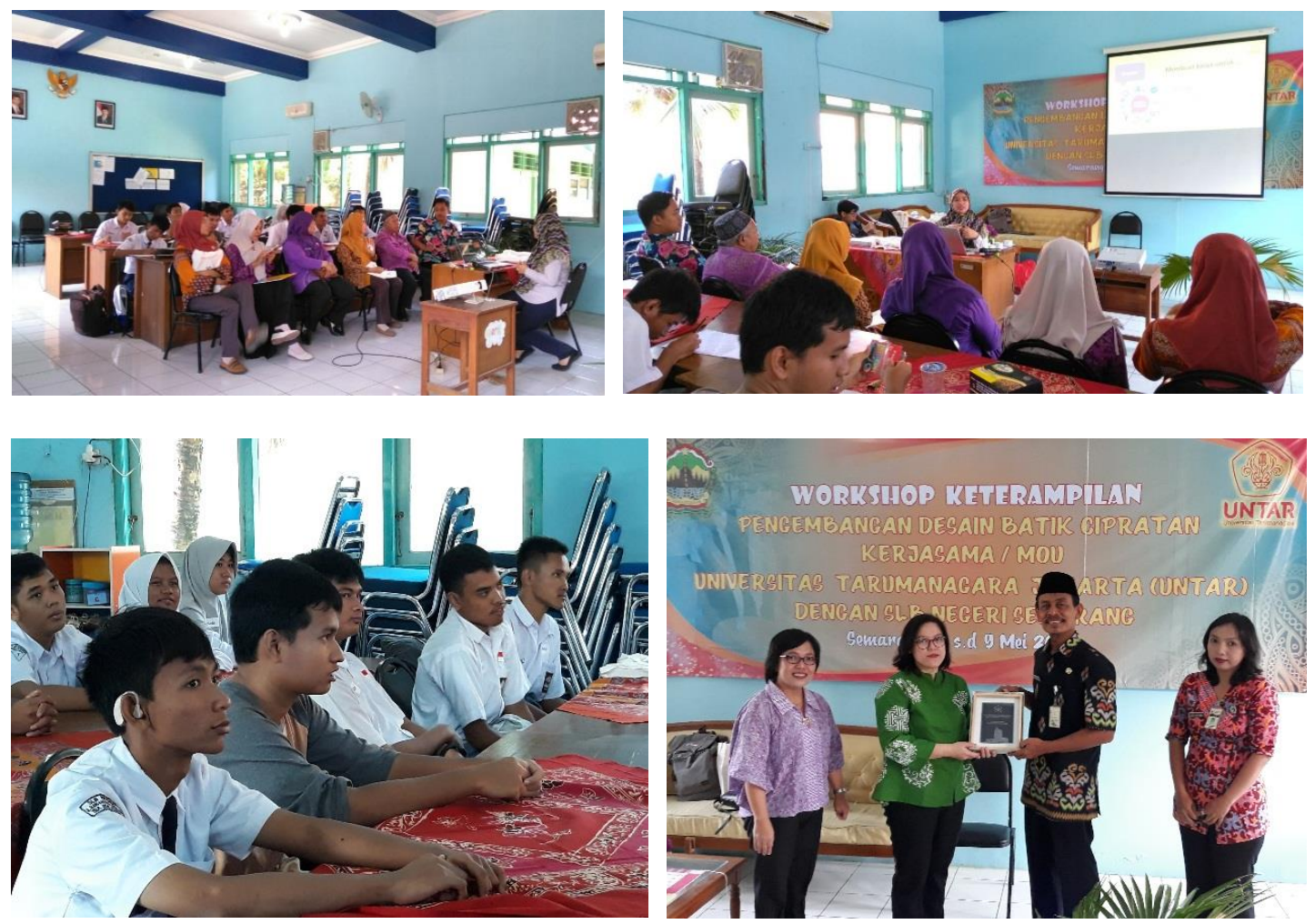

Gambar 6. Foto suasana pelatihan

Para peserta diberi kesempatan untuk mengeluarkan gagasan terkait ide visual dan juga ide cerita yang akan digunakan. Contoh ide cerita:" Batik Cipratan adalah batik tulis yang dibuat oleh tangan-tangan terampil siswa SLB, yang dibuat khusus setiap helainya, sehingga hasilnya tidak ada yang sama, unik dan eksklusif. Hal ini dapat divisualisasikan dengan memberikan visual siswa yang sedang melakukan kegiatan membatik, seperti pada Gambar 7.

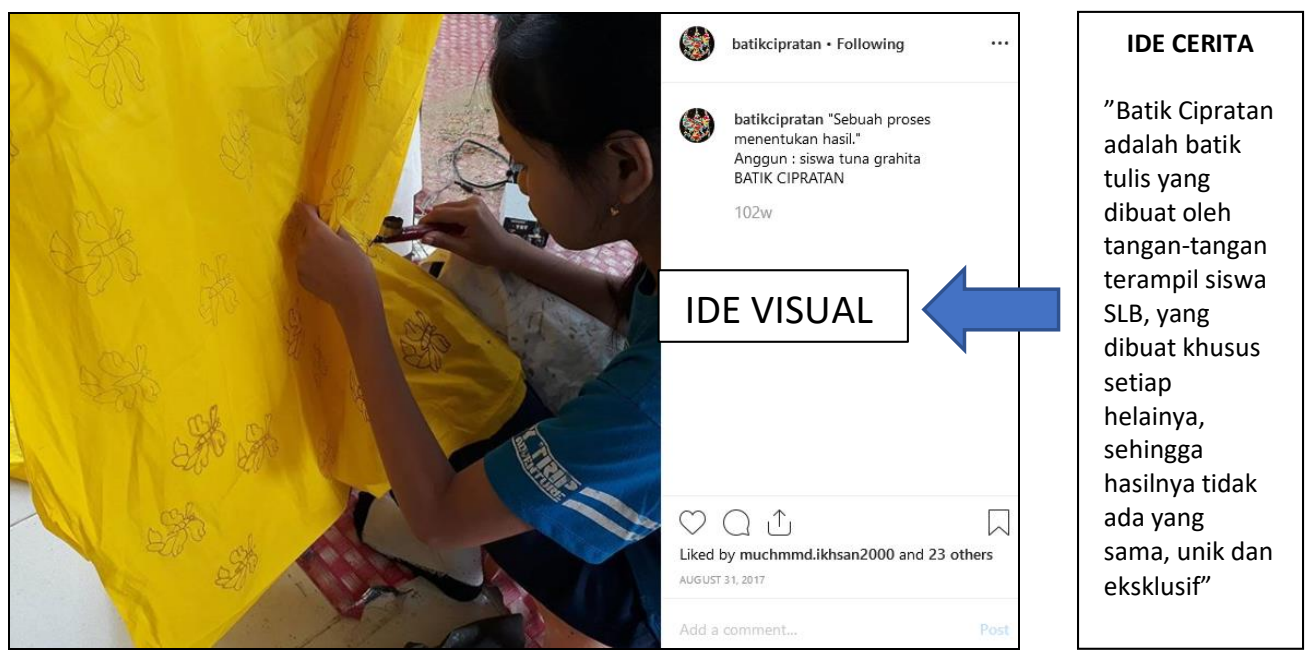

Gambar 7. Ide Cerita dan Ide Visual

Pada saat diskusi tidak ditemukan hambatan berarti, namun peserta menemukan masukan bahwa dalam membuat promosi diperlukan waktu dan tenaga yang khusus dalam perencanaannya. Pada sesi akhir pelatihan SLB Negeri Semarang disimpulkan bahwa diperlukan perencanan sekolah 
untuk membentuk tim khusus yang memang akan melaksanakan promosi menggunakan media online, karena tidak semua guru memiliki kompetensi dan minat dalam promosi produk serta tidak ikut dalam pembinaan di ekstra-kurikuler membatik.

\section{KESIMPULAN DAN SARAN}

Sekolah yang pada proses pembelajarannya menghasilkan berbagai macam produk perlu melakukan pengembangan wawasan dan pengetahuan mengenai promosi. Pelatihan ini memberikan pengetahuan dan wawasan bagi SLB Negeri Semarang untuk dapat mengoptimalkan proses promosi yang telah dilakukan sebelumnya. Pengenalan produk melalui promosi merupakan salah satu hal penting untuk menjaga eksistensi produk. Perkembangan teknologi membawa perubahan cara dalam mengenalkan produk, berbagai media sosial secara online bisa digunakan. Pemahaman mengenai pengelolaan media diperlukan dalam menyusun perencanaan promosi yang akan dilakukan.Elemen Visual dan Cerita dapat menjadi kekuatan dalam mengenalkan produk. Untuk kedepan diperlukan langkah pembentukan tim khusus dari pihak sekolah dalam melakukan promosi lebih lanjut.

\section{Ucapan Terima Kasih}

Ucapan terima kasih dan penghargaan diberikan kepada Direktorat Penelitian dan Pengabdian Masyarakat (DPPM) Universitas Tarumanagara yang telah memberikan dukungan dana hibah, dan juga Fakultas Seni Rupa dan Desain (FSRD) atas dukungan kelancaran sehingga proses pelaksanaan kegiatan pengabdian kepada masyarakat ini dapat terlaksana

\section{REFERENSI}

Rahman, Arif \& Tim Redaksi Money\&I. (2017). Creator Inc. Yogyakarta: Bentang Ulanat, Mini \& Jacob, K. Poulose. (2017). Facilitating Brand Promotion Through Online Social Media: A Business Case Study. Hybrid Intelligence for Social Networks. 207-225 Wardhana, Aditya. (2015). Strategi Digital Marketing dan Implikasinya Pada Keunggulan UKM Di Indonesia, Prosiding Seminar Nasional Keuangan dan Bisnis IV UPI. Bandung. $327-$ 337 